\title{
Atlas topographique de Lyon antique
}

Michel Lenoble

Édition électronique
URL : http://journals.openedition.org/adlfi/7119

ISSN : 2114-0502

Éditeur

Ministère de la culture

Référence électronique

Michel Lenoble, "Atlas topographique de Lyon antique », ADLFI. Archéologie de la France - Informations [En ligne], Rhône-Alpes, mis en ligne le 01 mars 2007, consulté le 01 mai 2019. URL : http:// journals.openedition.org/adlfi/7119

Ce document a été généré automatiquement le 1 mai 2019.

(c) Ministère de la Culture et de la Communication, CNRS 


\title{
Atlas topographique de Lyon antique
}

\author{
Michel Lenoble
}

Date de l'opération : 2001 - 2007 (PC)

1 L'atlas topograpique de Lyon antique a été mis en œuvre en 2001 dans le cadre d'un PCR. L'équipe est composée d'une vingtaine de chercheurs d'institutions diverses (INRAP, CNRS, Ville de Lyon, université, département du Rhône, DRAC-SRA, étudiants et bénévoles). L'atlas est réalisé selon les normes et la méthodologie initiées par et pour les atlas topographiques des villes de Gaule méridionale (Urbs antiqua) et pour lesquels Fréjus et Aix-en-Provence ont fait l'objet de publications dans les suppléments de la Revue archéologique de Narbonnaise.

2 Au cours de ces sept années de travaux, vingt-cinq feuilles ont été mises en œuvre. Elles se répartissent tant sur la partie sommitale de la colline de Fourvière que sur celle de la Croix-Rousse, dans la presqu'île et à Vaise. Ces feuilles sont de complexités variables allant des feuilles très riches en vestiges qui nécessitent plusieurs états chronologiques (théâtre, amphithéâtre, Verbe Incarné, forum, etc.), aux feuilles plus simples qui ne comportent qu'un seul état chronologique (Vaise, presqu'île). Une bibliographie générale de Lyon pour l'époque antique a été établie ainsi qu'une synthèse sur la géographie du site de Lyon qui est en cours. Les feuilles mises en œuvre sont engagées à des niveaux divers : certaines ne sont rédigées qu'au niveau des notices descriptives. Certaines feuilles ont fait l'objet de plusieurs lectures critiques devant les membres du PCR, et parfois du groupe Urbs antiqua. De manière générale le travail d'interprétation des vestiges est moins avancé que celui de rédaction des notices, l'objectif fixé étant de réaliser plusieurs feuilles d'un même quartier avant d'en proposer l'interprétation.

Pour compléter la rédaction des notices, des travaux de terrain (relevés topographiques, prospections) sont dans certains cas mis en œuvre afin de préciser l'état, la localisation, ou la description des vestiges encore visibles mais pour lesquels des précisions sont nécessaires (aqueducs, égouts, substructions existantes dans les caves, etc.). 
4 En 2007, les feuilles de l'Observance Pierre-Seize, de la Grotte Berelle (lycée Saint-Just), de Pauline-Marie-Jaricot, du quai Saint-Vincent, de Fourvière, du Chemin Neuf, de SaintJean et de Saint-Irénée ont été mises en œuvre; celles des théâtres de Fourvière et des Lazaristes ont été poursuivies.

5 LENOBLE Michel

INDEX

Index chronologique : Empire romain

Index géographique : Rhône-Alpes, Rhône (69), Lyon (69123)

operation Projet collectif de recherche (PCR)

\section{AUTEURS}

MICHEL LENOBLE

SRA 